\title{
Öğrencilerin Ara Tatil Uygulamasına Bakışı: Turhal Örneği^
}

\author{
Yasin Gökbulut ${ }^{\mathrm{a}}$
}

Ruhi Eroğlub

a Doç.Dr., Tokat Gaziosmanpaşa Üniversitesi, ORCID: 0000-0001-8554-1102

b Yüksek Lisans Üniversitesi, Tokat Gaziosmanpaşa Üniversitesi, ORCID: 0000-0002-0173-6971

\begin{abstract}
ÖZET
$\mathrm{Bu}$ araştırmanın temel amacı Millî Eğitim Bakanlığı'na bağlı ilk, orta ve lise kademesindeki okullarda 2019 yilında ilk defa uygulanan 'Ara Tatil' uygulaması ile ilgili öğrenci görüşlerinin tespit edilmesidir. Araştırmanın çalışma grubu Tokat ili Turhal İlçesinde öğrenim gören ve basit seçkisiz örnekleme yolu ile seçilen ilk, orta ve lise düzeyindeki toplam 497 öğrenciden oluşmaktadır. Araştırmada yöntem olarak nicel araştırma yöntemlerinden 'tarama modeli' kullanılmıştır. Öğlencilere dört bölümden oluşan ve araştırmacılar tarafından geliştirilen 19 soruluk anket uygulanmıştır. Öğrencilere uygulanan anketten alınan bilgiler SPSS 17.0 paket programı ile analiz edilmiştir. Verilen cevaplara ilişkin frekans, yüzdelik dağılımları, varyans, Bağımsız Grup t- Testi, Tek Yönlü Varyans (ANOVA) verileri hesaplanmış ve grafiklerle gösterilmiştir. Araştırma verilerinin analizi sonucunda öğrencilerin 2019 eğitim öğretim yılında ilk defa uygulanan 'Ara Tatil' uygulamasından memnun oldukları, öğrenci velilerinin de bu uygulamadan memnun oldukları, öğrencilerin 'Ara Tatil' uygulamasının devam etmesini istedikleri ancak milli eğitim müdürlüğünce ara tatil döneminde öğrenciler için hazırlanmış olan etkinliklerden yararlanamadıkları sonuçlarına ulaşılmıştır.
\end{abstract}

MAKALE BİLGİí Makale Türü

Araştırma

Makale Geçmişi

Gönderim tarihi:

17.06.2021

Kabul tarihi:

31.08.2021

Anahtar Kelimeler

Ara Tatil

Ara Tatil

Uygulamaları

Ara Tatil Etkinlikleri

Atıf Bilgisi: Gökbulut, Y. ve Eroğlu, R. (2021). Öğrencilerin ara tatil uygulamasına bakışı: Turhal örneği. Uluslararası Türk Ĕ̆itim Bilimleri Dergisi, 10 (17), 134-151.

Sorumlu yazar: Yasin Gökbulut, e-posta: yasin.gokbulut@gop.edu.tr

\footnotetext{
* Bu çalışma V. Uluslararası Türklerin Dünyası Sosyal Bilimler Sempozyumu'nda sözlü bildiri olarak sunulmuştur. Çalışma verileri 2019 yılında toplandığ 1 için etik kurul onayı gerekmemektedir.
} 


\title{
Students' Perspectives on the Midterm-Holiday Practice: Example of Turhal $^{*}$
}

\author{
Yasin Gökbulut ${ }^{\mathrm{a}}$
}

\author{
Ruhi Eroğlu $b$ \\ a Assoc.Prof.Dr., Tokat Gaziosmanpaşa University, ORCID: 0000-0001-8554-1102 \\ b Graduate Student, Tokat Gaziosmanpaşa University, ORCID: 0000-0002-0173-6971
}

\begin{tabular}{|c|c|}
\hline ABSTRACT & \\
\hline $\begin{array}{l}\text { The main purpose of this research is to examine the views of students about the } \\
\text { "Midterm Holiday" application, which was applied for the first time in } 2019 \text { in } \\
\text { primary, secondary, and high schools affiliated to the Ministry of National } \\
\text { Education. The study group of the research consists of } 497 \text { primary, secondary } \\
\text { and high school students studying in Turhal District of Tokat province and } \\
\text { selected by using simple random sampling. The survey design, one of the } \\
\text { quantitative research methods, was used as a method in the research. A } \\
\text { questionnaire with } 19 \text {-questions, consisting of four parts and developed by the } \\
\text { researchers, was administered to the students. The data were analyzed using the } \\
\text { SPSS } 17.0 \text { package program. Frequency, percentage distributions, variance, } \\
\text { Independent Group t-Test, One-Way Analysis of Variance (ANOVA) test were } \\
\text { used for the data analysis and results are shown using tables. As a result of the } \\
\text { study, the students were satisfied with the 'Midterm Holiday' application } \\
\text { implemented for the first time in the } 2019 \text { academic year, the parents of the } \\
\text { students were also satisfied with this application, the students wanted the } \\
\text { 'Midterm Holiday' application to continue, but they could not benefit from the } \\
\text { activities prepared for the students during the midterm holiday period by the } \\
\text { Directorate of National Education. }\end{array}$ & $\begin{array}{l}\text { Key Words } \\
\text { Midterm Holiday, } \\
\text { Midterm Holiday } \\
\text { Practice } \\
\text { Midterm Holiday } \\
\text { Activities }\end{array}$ \\
\hline
\end{tabular}

To cite this article: Gökbulut, Y. \& Eroğlu, R. (2021). Students' perspectives on the midterm-holiday practice: Example of Turhal. International Journal of Turkish Educational Sciences, 10 (17), 134-151.

Corresponding Author: Yasin Gökbulut, e-mail: yasin.gokbulut@gop.edu.tr

* This study was presented as an oral presentation at the 5th International Turkish World Social Sciences Symposium. Since the study data were collected in 2019, ethics committee approval is not required. 


\section{Giriş}

Türk eğitim sistemi cumhuriyetin ilk yıllarından günümüze kadar çeşitli değişikliklere uğramıştır. Bu değişiklikler kimi zaman eğitim sisteminin felsefesi ile beraber köklü bir değişim olmuş kimi zaman da sistemin eksik yönleri tespit edilerek küçük değişiklikler ile sisteme yenilikler eklenmesi ile olmuştur. 2012-2013 eğitim öğretim yılında 4+4+4 olarak bilinen 12 yıllık kesintisiz eğitim sistemi Türk eğitim sisteminde gerçekleştirilen değişimlere bir örnek verilebilir (Erdem ve Kıran,2016).

10/07/2019 tarih ve 30827 sayılı Resmi Gazete 'de yayımlanan Milli Eğitim Bakanlığı Okul Öncesi eğitim ve İlköğretim Kurumları Yönetmeliğinde Değişiklik Yapılmasına Dair Yönetmelik ve 12/07/2019 tarih ve 30829 sayılı Resmi Gazete' de yayımlanan Ortaöğretim Kurumları Yönetmeliğinde Değişiklik Yapılmasına Dair Yönetmelik ile Milli Eğitim bakanlığının 2019-2020 eğitim öğretim yılında ilk defa uygulamaya koyduğu 'Ara Tatil' uygulaması da eğitim sisteminin geçirdiği değişimlere bir örnek olarak gösterilebilir.

Tatil kelimesi Türk Dil Kurumu'nun güncel sözlüğünde 'Kanun gereğince çalışmaya ara verilebileceği belirtilen süre; Okul, meclis, adliye vb. kuruluşların çalışmasını durdurduğu veya kapalı bulunduğu dönem; Eğlenmek, dinlenmek amacıyla çalışmadan geçirilen süre' olarak tanımlanmıştır (TDK, 2021). Öğrenciler açısından tatilin örgün öğrenimlerine bir süre ara vermeleri anlaşılır. Öğrenime ara verilmesi, onların zamanlarını bomboş geçirmeleri demek değildir. Ara verme gereklidir. Çünkü birey bu dönemde harcadığı enerjisini yeniden kazanmak zorundadır (Tezcan, 1977).

Millî Eğitim Bakanlığı Okul Öncesi Eğitim ve İlköğretim Kurumları Yönetmeliği ile Millî Eğitim Bakanlığı Ortaöğretim Kurumları Yönetmeliği'nde ders yılı süreleri, resmî tatiller ve çalışma takvimi ile ilgili konuların olduğu bölümlerde 2019 yılı öncesinde daha önce olmayan 'Ara Tatil' ibaresi (RG-12/7/2019-30829) eklenerek öğrencilerin her biri bir dönemde olmak üzere yılda iki defa 'Ara Tatil' yapacakları belirtilmiştir. Orta öğretim kurumları yönetmeliğinin 15. Maddesinde 'Ders yılı iki döneme ayrılır ve her dönemde bir ara tatil yapılır. Ders yılının başlaması, ara tatiller, yarıyıl tatili, yaz tatili ile ders kesimi tarihleri Bakanlıkça belirlenir.' ibaresi ile ara tatilin zamanı tam olarak belirtilmemiş 'Ara Tatil' uygulamasının zamanının her yıl Bakanlıkça belirleneceği ifade edilmiştir. Yine okul öncesi eğitim ve ilköğretim kurumları yönetmeliğinin 5. Maddesinin 1. fırkasının a bendinde, 'Ders yılı, ara tatil, yarıyıl ve yaz tatilinin başlama ve bitiş tarihleri, Bakanlıkça her yıl düzenlenen çalışma takviminde belirtilir. Bu tarihler göz önünde bulundurularak hazırlanan il çalışma takvimi, il millî eğitim müdürlüklerinin önerisi ve valilik onayı ile yürürlüğe girer.' ibaresi ile ara tatilin zamanı tam olarak belirtilmemiş ve 'Ara Tatil' uygulamasının zamanının her yıl Bakanlıkça belirleneceği ifade edilmiştir.

Kısa adı EACEA olan Avrupa Komisyonu Avrupa Eğitim ve Kültür Yürütme Ajansı tarafından yayımlanan 'Avrupa'da Okul Zamanı Organizasyonu. İlk ve Genel Orta öğretim 2019/20' (The Organisation of School Time in Europe. Primary and General Secondary Education - 2019/20) raporunda Avrupa Birliği üye ülkeleri ile müzakereleri devam eden aday ülkelerin okul zamanları ayrıntılı bir şekilde verilmiştir. Rapora göre Avrupa ülkelerinin genelinde yaz tatilleri dışında dört tatil dönemi daha bulunmaktadır. Bunlar sonbahar tatilleri, Noel (yeni yıl), Kış (Karnaval) ve İlkbahar tatiller olarak gruplandırılmıştır. Sonbahar tatili sadece 11 ülkede uygulanmamaktadır. İkinci dönem ara tatil uygulaması uygulanmayan iki 
ülke olarak Karadağ ve Türkiye varken 2019 yılı itibari ile Türkiye de diğer Avrupa ülkeleri gibi ilkbaharda ara tatil uygulamasına geçmiştir (Doğan, 2020).

Tablo 1. Türkiye' de İlkokul ve Ortaokul Okul Süreleri Organizasyonu

İlk ve genel orta öğretimde okul zamanının organizasyonu-2019/20

\begin{tabular}{|c|c|c|}
\hline & İlköğretim & Genel orta öğretim \\
\hline $\begin{array}{l}\text { Öğrencilerin okul yılının } \\
\text { başlangıç tarihi }\end{array}$ & $\begin{array}{l}9 \text { Eylül } 2019 \text { (1. sınıf-5 Eylül } \\
\text { 2019) }\end{array}$ & $\begin{array}{l}9 \text { Eylül } 2019 \text { (1. sınıf-5 Eylül } \\
\text { 2019) }\end{array}$ \\
\hline Yar1 yıl tatili & 18-22 Kasım 2019 & 18-22 Kasım 2019 \\
\hline $\begin{array}{l}\text { Öğrencilerin okul yılının } \\
\text { sonu }\end{array}$ & 19 Haziran 2020 & 19 Haziran 2020 \\
\hline Noel/Yeni Y1l & 1 Ocak 2020 & 1 Ocak 2020 \\
\hline Kış/Karnaval & 2 hafta 20-31 Ocak 2020 & 2 hafta 20-31 Ocak 2020 \\
\hline Yar1 yıl tatili & 6-10 Nisan 2020 & 6-10 Nisan 2020 \\
\hline Yaz & $\begin{array}{l}12 \text { hafta } 19 \text { Haziran-7 Eylül } \\
2020\end{array}$ & $\begin{array}{l}12 \text { hafta } 19 \text { Haziran-7 Eylül } \\
2020\end{array}$ \\
\hline \multirow[t]{12}{*}{ Resmi/dini tatiller } & 29 Ekim 2019 & 29 Ekim 2019 \\
\hline & (1 gün Cumhuriyet günü) & (1 gün Cumhuriyet günü) \\
\hline & 1 Ocak 2020 & 1 Ocak 2020 \\
\hline & (1 gün Yeni yıl tatili) & (1 gün Yeni yıl tatili) \\
\hline & 23 Nisan 2020 & 23 Nisan 2020 \\
\hline & (1 gün Çocuk günü) & (1 gün Çocuk günü) \\
\hline & 1 Mayıs 2020 & 1 Mayıs 2020 \\
\hline & (1 gün İşçi günü) & (1 gün İşçi günü) \\
\hline & 19 Mayıs 2020 & 19 Mayıs 2020 \\
\hline & $\begin{array}{l}\text { (1 gün Gençlik ve Spor } \\
\text { günü) }\end{array}$ & $\begin{array}{l}\text { (1 gün Gençlik ve Spor } \\
\text { günü) }\end{array}$ \\
\hline & 23-25 Mayıs 2020 & 23-25 Mayıs 2020 \\
\hline & (2 gün Ramazan tatili) & (2 gün Ramazan tatili) \\
\hline $\begin{array}{l}\text { Öğretmenlerin eğitim } \\
\text { öğretim yılının başlama } \\
\text { tarihi }\end{array}$ & Eylül başı & Eylül başı \\
\hline $\begin{array}{l}\text { Öğretmenlerin eğitim } \\
\text { öğretim yılının sonu }\end{array}$ & Haziran başı & Haziran başı \\
\hline
\end{tabular}


Rapora göre Avrupa Birliği ve aday ülkelerin çoğunda ara tatil uygulaması uygulanmaktadır. Raporda Türkiye'nin de Kasım ve Nisan aylarında olmak üzere yılda iki defa ara tatil uyguladığı Tablo 1'de gösterilmektedir.

Tablo 1'e göre Avrupa ülkelerinin çoğunda olduğu gibi Türkiye'de de okullar sonbahar mevsiminde başlamakta, eğitim süreleri iki yarı yıldan oluşmakta ve yaz mevsiminde kapanmaktadir.

Avrupa Komisyonu Avrupa Eğitim ve Kültür Yürütme Ajansı tarafından yayımlanan 'Avrupa'da Okul Zamanı Organizasyonu. İlk ve Genel Orta öğretim - 2019/20' (The Organisation of School Time in Europe. Primary and General Secondary Education - 2019/20) raporunda okul yılı uzunluğu ve tatil süreleri Şekil 1'de gösterilmiştir. 


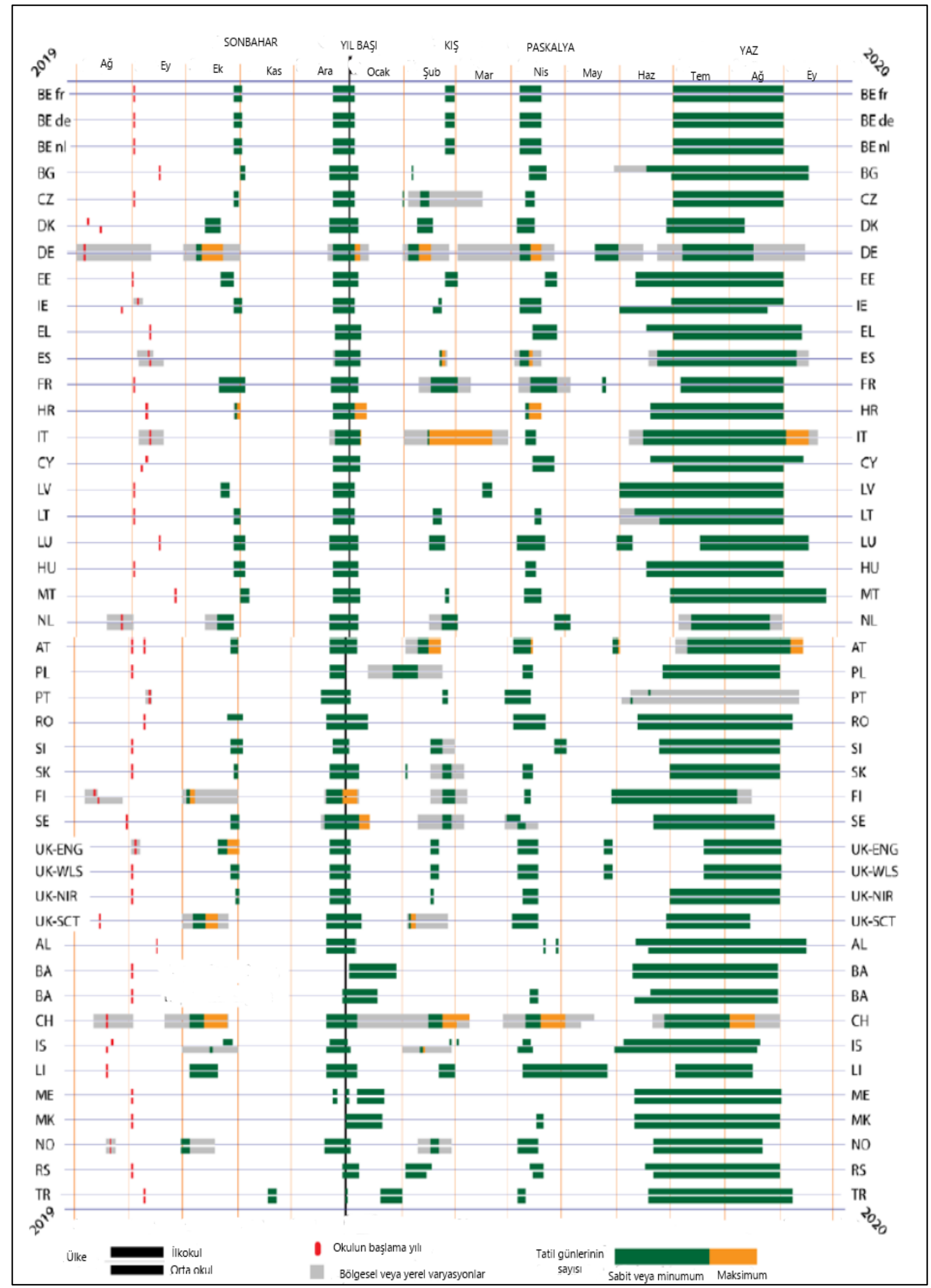

Şekil 1. Okul Yılı Uzunluğu ve Tatil Sürelerinin Dağılımı, (ISCED 1-3, 2019/20) 
Şekil 1'de, Avrupa Birliğine üye ülkeler ile aday ülkelerin okul yılı uzunlukları ve tatil sürelerinin verildiği şekil incelendiğinde ülkelerin çoğunda ara tatil uygulandığ1 görülmektedir. Yaz tatilleri dışında ise dört grup tatil olduğu görülmektedir. Sonbahar mevsiminde ülkelerin hemen hemen hepsinde ara tatil olduğu, birkaç ülkede (Çek Cumhuriyeti, Birleşik Krallık- Kuzey İrlanda ve İzlanda) iki veya üç gün olarak uygulandığı, diğer ülkelerde ise bir hafta olarak uygulandığı görülmektedir. İsviçre'de 3 haftalık bir ara tatil süresi varken 11 Avrupa Birliği ülkesinde ara tatil uygulaması bulunmamaktadır.

Avrupa Komisyonu Avrupa Eğitim ve Kültür Yürütme Ajansı tarafından yayımlanan 'Avrupa'da Okul Zamanı Organizasyonu. İlk ve Genel Orta öğretim - 2018/19' (The Organisation of School Time in Europe. Primary and General Secondary Education - 2018/19) 2018 raporunda Türkiye' de İlkbahar mevsiminde ara tatil görünmemektedir. 2019 Kasım ayında ilk defa uygulanan 'Ara Tatil' uygulamasını takiben 2020 Nisan ayında ikinci ara tatil uygulanmış ve Türkiye' de ilkbahar mevsiminde ara tatil uygulayan ülkeler arasına katılmıştır. 2018 yılı raporunda ara tatili olmayan iki ülke olarak Karadağ ve Türkiye olarak belirtilirken 2019 raporunda ara tatil uygulamayan tek ülke Karadağ olarak belirtilmiştir.

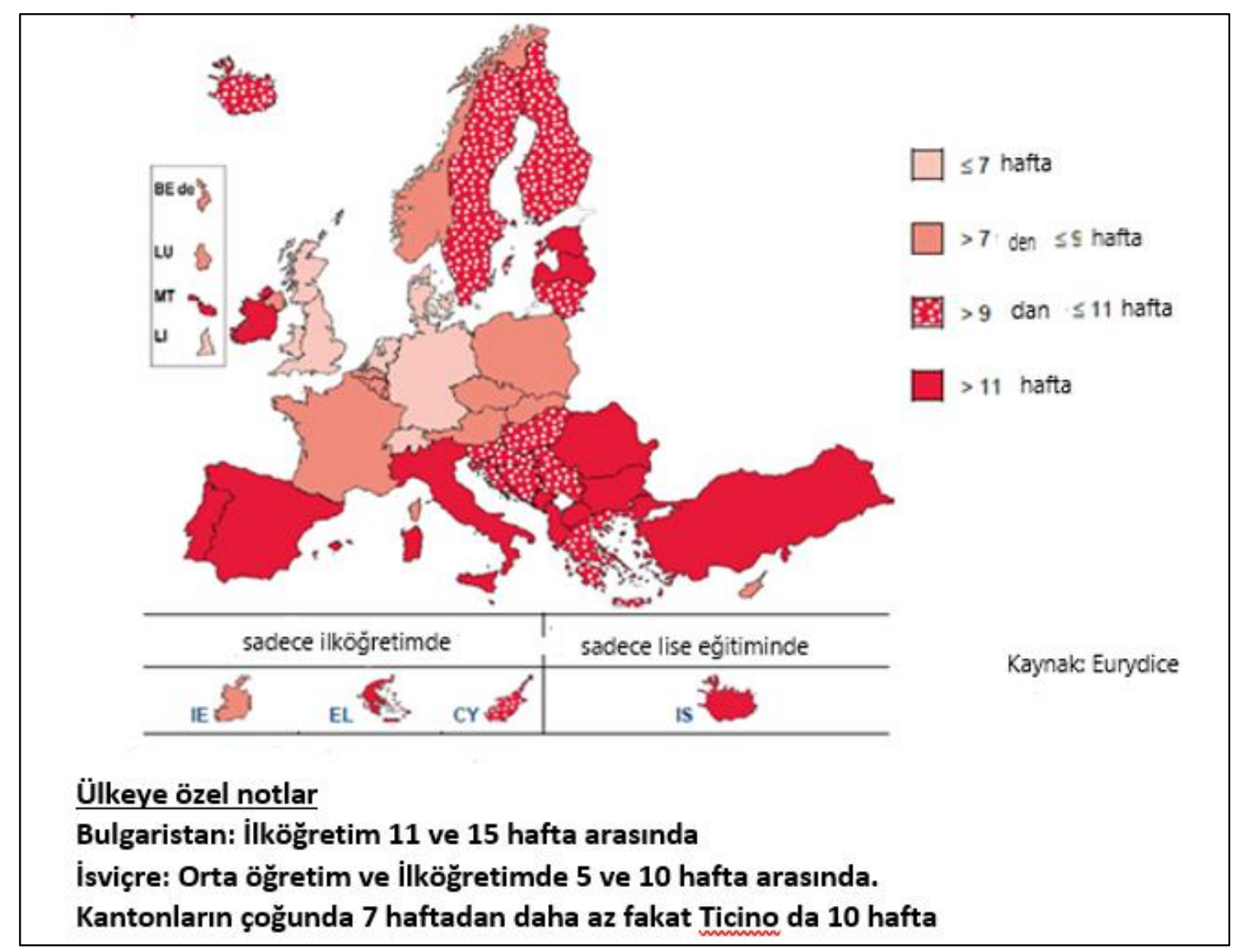

Şekil 2. Avrupa Birliği Ülkelerinde Hafta Olarak Yaz Tatillerinin Uzunluğu

(The Organisation of School Time in Europe - European Commission/EACEA/Eurydice, 2019.)

Şekil 2'de Avrupa Birliğine üye ülkeler ile aday ülkelerin hafta olarak yaz tatilleri süreleri verilmiştir. Raporda her ne kadar Türkiye'nin yaz tatili süresi 11 haftadan büyük olarak 
gösterilmişse de uygulamada Türkiye'de yaz tatili yeni uygulama ile 11 hafta olarak uygulanmaktadir.

Avrupa birliği ülkelerinin çoğunda yıllardır var olan ancak Türkiye'de 2023 vizyonu çerçevesinde planlanıp 2019 yılı Kasım ayında uygulanan 'Ara Tatil' uygulaması Türk eğitim sisteminde gerçekleştirilen son değişikliklerden biri olmuştur. Eğitim sisteminin tüm paydaşları için ilk olan bu uygulamanın özellikle öğrenciler açısından nasıl karşılandığının bilinmesi önem arz etmektedir. Çünkü ara tatil ile ilgili paydaş görüşlerinin alınması sonraki ara tatillerin planlamasının daha doğru ve düzgün yapılabilmesinin önünü açacaktır. 'Ara tatil' uygulamasına öğrencilerin bakışlarının ve ara tatil sürecinde hangi etkinlikleri gerçekleştirdiklerinin ilkokul, ortaokul ve lise düzeylerinde bütüncül bir bakış açısı ile tespit edilmek istendiği bu çalışmanın her sene yapılması planlanan 'Ara Tatil' uygulamasının geliştirilmesine katkı sunması beklenmektedir.

Millî Eğitim Bakanlığı'nca 15.05.2019 tarihinde yapılan açıklama ile 2023 vizyonu çerçevesinde yeni bir uygulamaya geçileceği belirtilmiştir. Milli Eğitim bakanlığınca, eğitim öğretim yılının çalışma takvimi ile ilgili olan bu değişikliğin uzun zamandır üzerinde tartışılan, fikir yürütülen, toplumdaki değişimlere paralel bir takvim değişikliği olduğunu belirtmiştir. Yeni çalışma takvimine göre 180 iş günü olan çalışma takviminde bir değişiklik yapılmazken 13 haftalık yaz tatil süresinin iki haftası nisan ve kasım aylarında yapılacak olan birer haftalık ara tatil olarak planlanmıştır. Bu değişiklikle tatil süreleri ve okul zamanlarının daha verimli ve dengeli olması planlanmıştır. Bu verimlilikler, Öğretmenlerin hizmet içi eğitimleri açısından verimlilik, derslerin daha etkili işlenişi açısından verimlilik, öğretmenlerin sınıf içi yaptığ proje ve çalışmalar açısından verimlilik ve Millî Eğitim Bakanlığının yürüttüğü işlemler açısından verimlilik şeklinde sıralanmaktadır. (Doğan, 2020)

Millî Eğitim Bakanlığı'nca yapılan açıklamada ayrıca ara tatil ve çalışma takvimindeki değişiklikler ilgili amaçlar ve esaslar şu şekilde belirtilmiştir (MEB, 2019).

- Ara Tatil uygulamasının temel amacı verimliliği arttırmaktır. Burada verimlilikten kasıt öğretmen eğitimi açısından verimlilik, derslerin işlenişi açısından verimlilik,

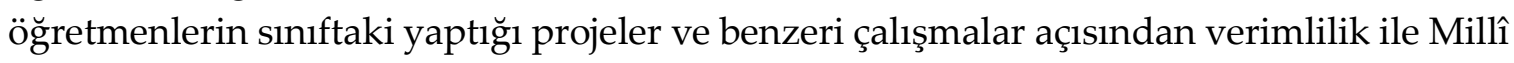
Eğitim Bakanlığının yaptı̆̆ı tüm iş ve işlemler açısından verimliliktir.

- Öğrencilerin öğrenme eksikleri bu dönemde telafi edilebilecektir.

- Ara tatil sadece tatil olarak düşünülmeyecek bu süreçte çeşitli etkinlikler düzenlenerek öğrenciler bu etkinliklere katılabilecektir.

- 180 iş günlük çalışma takvimi esas alınarak yaz tatili süresi kısaltılacaktır.

- Yaz tatili süresinden alınan iki haftalık süre nisan ve kasım aylarında birer hafta olmak üzere ara tatil süresi olarak kullanılacaktır.

- Öğrencilerin toplam tatil sürelerinde bir kısalma olmayacaktır.

- Ara tatillerde öğretmenler okulda olacak ve mesleki çalışmalarını yerine getireceklerdir. 
- 2019-2020 eğitim öğretim yılında ilk defa uygulanacak olan ara tatil uygulaması ilk olarak birinci dönem 18-22 Kasım 2019 tarihleri arasında, ikinci dönem ise 6-10 Nisan 2020 tarihlerinde uygulanacaktır.

- Öğrencilerin tatilde olduğu ara dönemler, öğretmen ve okulların kurumsal işleyişe yönelik ara değerlendirmelerle gerekli iyileştirmeleri yapabilmeleri için de bir fırsat olacak. Ara tatillerde veli toplantıları, zümre toplantıları, mesleki gelişim çalışmaları, kişisel ve sosyal gelişim etkinlikleri, okulların fiziki yenilenmeleri yapılacak.

Öğrenciler tatilde boş zaman faaliyetleriyle kendi yeteneklerini keşfetme olanağı bulur ve bu kişiliğini daha iyi tanıma fırsatı elde eder (Tezcan 1977). Millî Eğitim Bakanlığı tarafından 2019 yılında ilk defa uygulanan 'Ara Tatil' uygulaması da öğrencilerin sadece tatil yapmalarını değil aynı zamanda bilimsel, kültürel, sanatsal ve sportif etkinliklere katılımlarını sağlamayı amaçlamıştır. Öğrencilerin ara tatil döneminde katılabilecekleri çeşitli etkinliklerin düzenlenmiş ve bu etkinlikler bakanlığın internet sitesinde yayımlanmıştır (MEB Ara Tatil 2019). Bakanlık tarafından öğrenci ve veliler için hazırlanmış etkinlikler illere göre listelenecek bir internet sayfası ara yüzü ile sunulmuş ve öğrencilerin bulundukları ilde hangi etkinliklerin olduğunu gün gün görerek istedikleri etkinliklere katılabilmeleri sağlanmıştır.

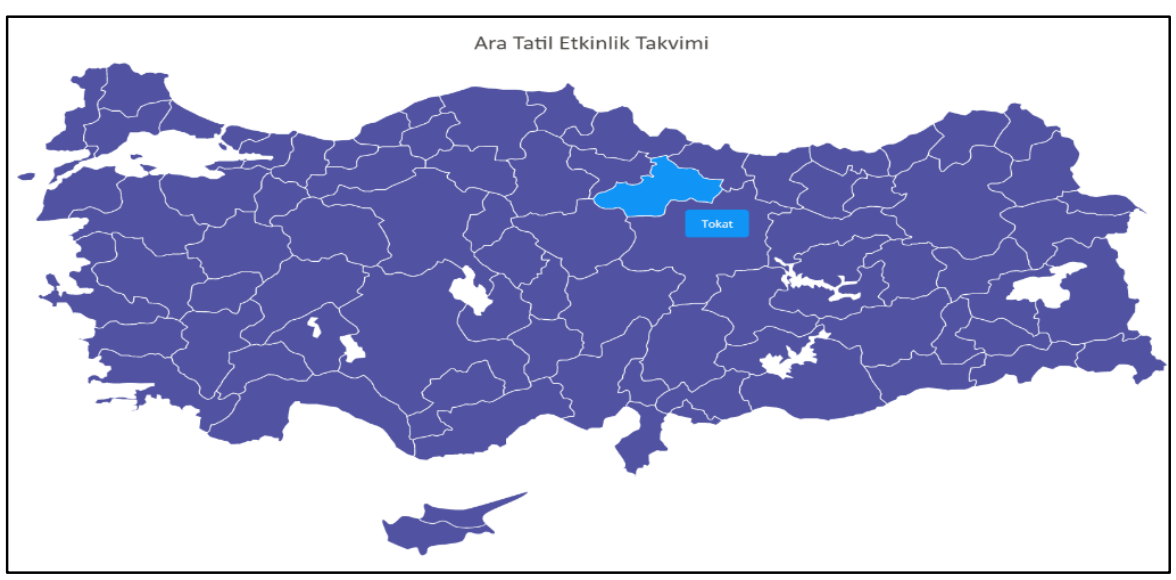

Şekil 3. Ara Tatil Etkinlikleri

(aratatil.meb.gov.tr)

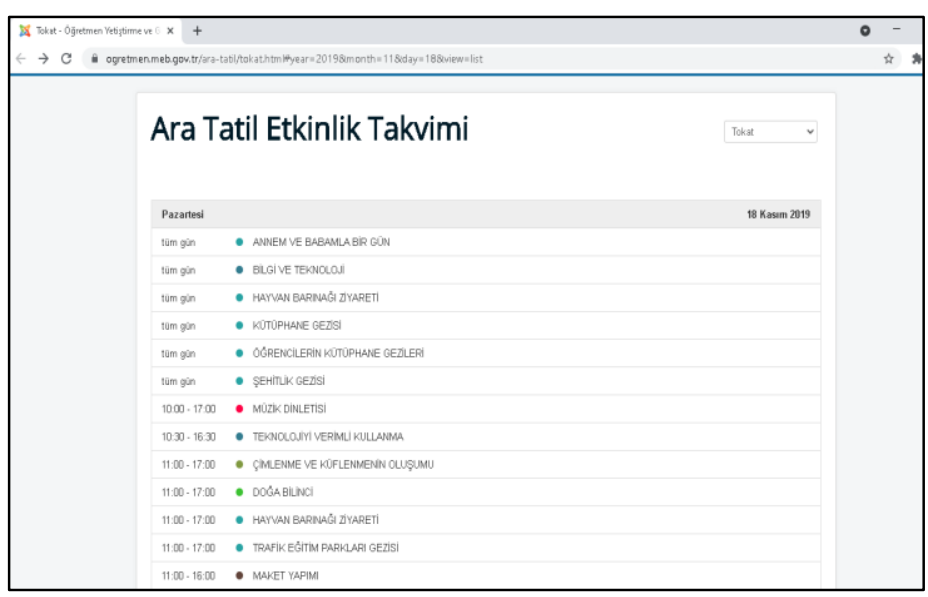

Şekil 4. Ara Tatil Etkinlikleri 2

(aratatil.meb.gov.tr) 
Şekil 3 ve Şekil 4'te Millî Eğitim Bakanlığı'nca hazırlanan, öğrenci ve velilerin bulundukları illerde hangi etkinliklerin yapıldığını gösteren interaktif uygulamanın ekran görüntüsü yer almaktadır. Bu web tabanlı uygulama sayesinde www.aratatil.meb.gov.tr adresinden hangi ilde hangi etkinliğin olduğu görülebilmektedir. Milli Eğitim Bakanlı̆̆ınca ara tatilde öğrencilerin farklı illere seyahat edebilecekleri düşünülerek öğrencilerin tatilde bulundukları herhangi bir ilde bu etkinliklere katılabilmeleri hedeflenmiştir. Web sayfasında ayrıca etkinliğin kategorisi, tarihi, konumu, etkinliği oluşturan birim ve hedef kitlesi de ayrıca belirtilmiştir.

'Ara Tatil' uygulaması ile ilgili yapılan çalışmalar incelendiğinde ara tatilin öğretmenler ve öğrenciler tarafından nasıl algılandığı, uygulama ile ilgili öğrencilerin neler düşündüklerini inceleyen çalışmalara rastlanmıştır. Daha çok öğretmen görüşlerini yansıtan bu çalışmalardan yalnızca birinde ortaokul öğrencilerin görüşlerinin incelendiği görülmüştür. Kurtoğlu ve diğerleri (2021)'e göre öğretmenlerin ara tatilin okumayı öğrenme sürecine etkisini olumlu gördükleri, ara tatilin öğrencilerin okula uyumlarını kolaylaştırdığını ve dolayısı ile okuma yazma öğrenme sürecine katkı sağladığı ancak ara tatilin yazmayı öğrenme sürecine etkisinin okumaya olan etkisi gibi net olmadığı tespit edilmiştir. Ara tatilin okuma ve yazma öğrenme süreçlerini olumlu ya da olumsuz yönde etkilemesinin; okul türlerine, velilerin ilgi ve desteğine, öğretmenlerin ara tatilde yaptıkları çalışmalara, teknolojik olanaklara vb. bağlı olduğu ayrıca belirtilmiştir.

Kaya (2020)'de mesleki çalışmaların ara tatilde yapılmasının öğretmenler tarafından olumlu karşılandığı, ortaokul öğrencilerinin ara tatil uygulamasından memnun oldukları ve uygulamanın devam etmesi yönünde fikir belirttikleri sonucuna varılmıştır. Kaya, karar vericilerin paydaşların görüşleri alınmadan uygulamaya konulan ara tatil uygulamasının doğru bir karar olduğu ayrıca belirtilmiştir.

Doğan (2020)` de öğretmenlerin ara tatil ile ilgili belirttikleri olumlu ve olumsuz görüşler olduğu ancak olumlu tarafın biraz daha ağır bastığı belirtilmiştir. Öğrencilere tatilde dinlenme olanağı sunması, onları motive edeceği, öğrenci başarısının artacağı, öğrencinin sosyalleşmesine imkân sağlayacağı yönündeki olumlu görüşleri yansıtmaktadır. Birinci sınıf öğrencilerde görülen gerileme, okuma yazmada görünen olumsuz etki, çalışan ailelerin çocukları için boş bir hafta olarak geçirildiği ise olumsuz görüşler olarak yansıtılmıştır. Araştırmada ayrıca sınıf öğretmenleri açısından çok fazla bir fark yaratmadığı da belirtilmiştir.

Eğitim sürecinde bir ara verme olduğu için tatil, öğrenciler tarafından istekle beklenen bir durumdur. Burç ve Karakuyu (2020)'de sınıf öğretmenlerinin eksikliklerini giderme açısından, öğrencilerde de dinlenme ve aileler ile vakit geçirme açısından olumlu karşılandığı belirtilmiştir. Ancak velilerin çoğunluğu çalışan anne babalar olduğu için uygulamadan olumsuz etkilenildiğine de değinilmiştir.

Ara tatil uygulamasına yönelik yapılan çalışmalar ışı̆̆ında ülkemizde de hali hazırda ara tatil uygulaması üçe çıkartılmışken öğrencilerin ara tatil uygulamasına bakışlarının incelenmesi önem arz etmektedir. Bu doğrultuda araştırmanın amacı Tokat ili Turhal İlçesinde öğrenim gören öğrencilerin 2019 yılında ilk defa uygulanan 'Ara Tatil' uygulaması ile ilgili görüşlerini tespit etmektir. Bu amaç doğrultusunda;

1. 'Ara Tatil' uygulaması ile ilgili öğrencilerin görüşleri nelerdir? 
2. 2019 yılında ilk defa uygulanan 'Ara Tatil' uygulaması ile ilgili öğrenciler ne hissetmektedirler?

3. 'Ara Tatil' uygulaması sürecinde öğrenciler nasıl vakit geçirmiştir?

4. 'Ara Tatil' uygulaması sürecinde öğrenciler kendilerine sunulan etkinliklere ne derece katılmıştır?

Sorularına cevap aranmıştır.

\section{Yöntem}

‘Ara Tatil' uygulamasına öğrencilerin bakışının ölçülmek istendiği bu çalışmada araştırma, nicel araştırma yöntemlerinden tarama modeli ile kurgulanmıştır. 'Tarama modeli, geçmişte var olmuş olan ya da hâlen var olan bir durumu olduğu şekliyle betimlemeye çalışan yaklaşımdır. Araştırmaya konu olan olay, birey ya da nesne, kendi koşulları içinde ve olduğu gibi tanımlanmaya çalışılır. Onları, herhangi bir şekilde değiştirme, etkileme çabası gösterilmez. Bilinmek istenen zaten ordadır. Önemli olan onu gözlemleyip uygun bir biçimde belirleyebilmektir.' (Karasar, 2012, s. 77). Araştırmaya konu olan öğrenciler kendi koşulları içerinde olduğu gibi tanımlanmaya çalışılır. Tarama çalışmasında çalışma grubunu etkileme çabası gösterilmez. Öğrenilmek istenen bilgi tarafsızca gözlemlenip mevcut durum uygun bir biçimde ortaya konulur.

\section{Evren ve Örneklem}

Araştırma çalışmasının evrenini 2019-2020 eğitim öğretim yılında Tokat ili Turhal ilçesinde öğrenim gören ilk, orta ve lise öğrencileri oluşturmaktadır. Araştırmanın çalışma grubunu basit random örnekleme yolu ile seçilen 589 öğrenci oluşturmaktadır. 'Basit tesadüfi örneklemede tüm birimler eşit şansa sahiptir. Evren çok büyük ve karmaşık değilse seçme işlemi kolaydır ve bu yöntemle yapılan örneklemede istatistiksel işlemler ağırlıksız olarak yapıldığı için değerlendirme işlemi ve örnekleme hatası kolayca hesaplanabilir.' (Kılıç, 2013, s.45).

Araştırmaya katılan öğrencilere ait demografik bilgiler şu şekildedir:

Tablo 2. Demografik Bilgiler

\begin{tabular}{llll}
\hline \multirow{2}{*}{ Cinsiyet } & \multicolumn{1}{l}{ Erkek } & K1z & \\
\cline { 2 - 4 } Okulun bulunduğu yerleşim yeri & 271 & 318 & \\
\cline { 2 - 4 } & İlçe merkezi & Belde & Köy \\
\cline { 2 - 4 } Okul seviyesi & 383 & 53 & 153 \\
& İlkokul & Ortaokul & Lise \\
\cline { 2 - 4 } & 189 & 215 & 185 \\
\hline
\end{tabular}




\section{Veri Toplama Araçları}

Öğrencilerin 2019/2020 eğitim öğretim yılında ilk defa uygulanan 'Ara Tatil' uygulamasına bakışlarının ölçülmek istendiği bu çalışmada 589 öğrenciden oluşan araştırma grubuna 19 soru sorulmuştur. Ankette bulunan ilk dokuz soru öğrencilerin ara tatil ile ilgili görüşlerini, ara tatili nasıl geçirdiklerini ve ara tatilde neler yaptıklarını tespit etmeye yönelik sorulardan, diğer on soru ise ara tatilde kendileri için hazırlanan etkinliklere katılımları ile ilgili görüşlerini tespit etmeye yönelik sorulardan oluşmaktadır.

‘Thomas (1998) anketi, insanların yaşam koşullarını, davranışlarını, inançlarını veya tutumlarını betimlemeye yönelik bir dizi sorudan oluşan bir araştırma materyali olarak tanımlamaktadır.' (Büyüköztürk, 2005). Büyüköztürk'e (2005) göre, anket hazırlamaya çalışmanın anahtar kelimeleri ile ilgili bir literatür çalışması yapılarak başlanır. Anket hazırlamada problem tanılama adı verilen bu süreç ne kadar sistematik yapılırsa araştırmanın genel ve alt amaçlarına ulaştırılması o kadar kolay olur.

Anket hazırlama sürecinde daha sonra madde yazım aşamasına geçilmiş, hedef kitleden küçük bir gruba kompozisyon yazdırılarak içerik analizi yöntemi ile soru ifadeleri oluşturulmuştur. Soru ifadeleri oluşturulduktan sonra daha önce hazırlanan madde havuzundan maddeler seçilerek Anket Taslak Formu oluşturulmuştur. Çalışmanın bu aşamasında meslektaş ve uzman görüşlerine başvurulmuştur. Anketin kapsam geçerliliğinin belirlenmesi için Uzman Değerlendir formu oluşturularak uzman görüşü alınmış ve alınan dönütlere göre anket taslak formu oluşturulmuştur. Anket oluşturma çalışmasının son aşamasında oluşturulan Ön Uygulama Formu ile araştırmanın hedef kitlesine benzer özelliğe sahip bir grup üzerinde ön uygulama yapılmıştır. 20 sorudan oluşan Ön Uygulama Formu sonuçlarında hazırlanan sorulardan birinin kapsam geçerliliği ve güvenirliği düşük çıktığından anket formundan çıkarılarak anket 19 soru ile uygulanmıştır. Araştırma için geliştirilen anket üçlü likert tipte olan derecelendirme ölçeği şeklinde hazırlanmıştır. Üçlü likert tipi ölçekte 'katılmıyorum', 'kararsızım' ve 'katılıyorum', ifadeleri yer almaktadır.

Anketin birinci bölümünde anketin uygulanış amacı ile ilgili bilgiler, ikinci bölümde katılımcılar ile ilgili demografik bilgiler, üçüncü bölümde anketin uygulanışı ile ilgili yönergeler ve dördüncü bölümde de ara tatil ile ilgili sorular bulunur.

Araştırmada kullanılacak anketin uygulanabilmesi için Millî Eğitim Bakanlığı Yenilik ve Eğitim Teknolojileri Genel Müdürlüğünün 22.08.2017 tarih ve 12607291 sayılı 2017/25 nolu "Araştırma, Yarışma ve Sosyal Etkinlik İzinleri" konulu genelgesi gereği gerekli izinler alınmış ve uygulama yapılmıştır. Yeterli sayıda çoğaltılan anket formu Tokat ili Turhal ilçesinde öğrenim gören öğrencilerden basit random örnekleme yolu ile seçilen çalışma gruplarına birebir uygulanmıştır. Veri toplama süreci 16.12.2019 tarihinde başlayarak sürecin 14.02.2020 tarihinde tamamlanmıştır.

Hazırlanan anketi uygulamadan önce okul idarecileri ve katılımcılarla görüşülüp anket hakkında ön bilgi verilmiş, samimi ve gönüllülük esasına göre cevaplamaları istenmiştir. Anket için elde edilen verilerin sadece bilimsel amaçlar için kullanılacağı ve ayrıca isim yazmalarına gerek olmadığı da ayrıca belirtilmiştir. 


\section{Verilerin Analizi}

Öğrencilere uygulanan anketten elde edilen verilerin analizinde SPSS 22 istatistik paket programı kullanılmıştır. Verilen cevaplara ilişkin frekans, yüzdelik dağılımları, varyans, Bağımsız Grup t- Testi, Tek Yönlü Varyans (ANOVA) verileri hesaplanmıştır.

Yapılan faktör analizi sonucunda KMO değerinin. 85 olduğu görülmüş ve ölçeğin 5 faktörden oluştuğu belirlenmiştir. Bu 5 faktörün ölçeğe ilişkin açıkladıkları varyans 59,29'dur. Maddelerle ilgili olarak tanımlanan 5 faktörün ortak varyansları. 48 ile .66 arasında değişmektedir. Buna göre analizde önemli olarak ortaya çıkan 5 faktörün birlikte, maddelerdeki toplam varyansın ve ölçeğe ilişkin varyansın çoğunluğunu açıkladığı görülmektedir.

Ölçekte yer alan tüm maddeler için madde - toplam korelasyonları .33 ile .59 arasında değişmekte ve $t$ - değerlerinin anlamlı olduğu görülmektedir. Ölçeğin Cronbach Alfa iç tutarlık güvenirlik ölçümü .82 'dir. Bu sonuçlar ölçekteki maddelerin geçerliklerinin yüksek olduğu, yöntemsel yeterlilikler bakımından öğrencileri ayırt ettiği belirlenmiştir.

Çalışma verileri 2019 yılında toplandığı için etik kurul onayı gerekmemektedir.

\section{Bulgular}

\section{Ara Tatil ile İlgili Öğrenci Görüşlerine Dair Bulgular}

Aşağıda yer alan Tablo 2'de ara tatil ile ilgili öğrenci görüşlerinin ne olduğu, ara tatil ile ilgili ne hissettikleri ve ara tatil döneminde nasıl vakit geçirdiklerine dair soruların cevaplarına ilişkin veriler yer almaktadır. 
Tablo 3. Ara Tatil ile İlgili Öğrenci Görüşleri

\begin{tabular}{|c|c|c|c|c|c|c|}
\hline \multirow[b]{2}{*}{ Öğrenci görüşleri } & \multicolumn{2}{|c|}{ Katılmiyorum } & \multicolumn{2}{|c|}{ Kararsizim } & \multicolumn{2}{|c|}{ Katıliyorum } \\
\hline & $\mathrm{f}$ & $\%$ & $\mathrm{f}$ & $\%$ & $\mathrm{f}$ & $\%$ \\
\hline 1.Ara tatilde kendimi daha mutlu hissettim & 90 & 15,3 & 75 & 12,7 & 424 & 72 \\
\hline 2.Ara tatilde dinlenme firsatı buldum & 76 & 12,9 & 50 & 8,5 & 463 & 78,6 \\
\hline 3.Ara tatilde ödev yaparak zaman geçirdim & 136 & 23,1 & 158 & 26,8 & 295 & 50,1 \\
\hline $\begin{array}{l}\text { 4.Ara tatilde ailemle birlikte daha fazla } \\
\text { zaman geçirdim }\end{array}$ & 87 & 14,8 & 79 & 13,4 & 423 & 71,8 \\
\hline 5.Ara tatilde bolca oyun oynadım & 227 & 38,5 & 142 & 24,1 & 220 & 37,4 \\
\hline 6.Ara tatilin her sene uygulanmasını isterim & 117 & 19,9 & 95 & 16,1 & 377 & 64 \\
\hline $\begin{array}{l}\text { 7.Ara tatil uygulamasının bir hafta sürmesi } \\
\text { yeterlidir }\end{array}$ & 211 & 35,8 & 109 & 18,5 & 269 & 45,7 \\
\hline 8.Ara tatil uygulaması daha sık yapılmalıdır & 209 & 35,5 & 119 & 20,2 & 261 & 44,3 \\
\hline $\begin{array}{l}\text { 9.Ara tatil uygulaması aile bireylerini mutlu } \\
\text { etti }\end{array}$ & 135 & 22,9 & 153 & 23 & 301 & 51,1 \\
\hline
\end{tabular}

Tablo 3'te görüldüğü gibi 'Ara tatilde kendimi mutlu hissettim.' Olarak görüş belirten öğrencilerin sayısı $f=424$ (\%72) tür. Bu bölümde öğrencilerin en çok katıldığı görüş $f=463$ kişi ile $(\% 78,6)$ 'Ara tatilde dinlenme fırsatı buldum.' seçeneği olmuştur. Üçüncü en çok tercih edilen seçenek ise $f=423$ kişi $(\% 71,8)$ ile 'Ara tatilde ailemle birlikte daha fazla zaman geçirdim.' Seçeneği olmuştur.

Ara tatili ödev yaparak geçirdiğini belirten öğrencilerin sayısı $f=295(\% 50,1)$ iken ara tatilde bolca oyun oynadığını belirten öğrencilerin sayısı $f=220(\% 37,4)$ olarak görülmektedir. $f=227$ öğrenci $(\% 38,5)$ ise ara tatilde bolca oyun oynamadıklarını belirtmiştir.

Ara tatilde kendini mutlu hisseden öğrenci sayısı $f=424(\% 72)$ iken ara tatilin her sene devam etmesi yönünde görüş belirten öğrenci sayısı $f=377$ (\%64) olmuştur. Yine ara tatil uygulamasının daha sık yapılması yönünde görüş belirten öğrenci sayısı $f=261(\% 44,3)$ olmuştur.

Ara tatil uygulamasının süresi ile ilgili sorulan 'ara tatil uygulamasının 1 hafta sürmesi yeterlidir' sorusuna katılıyorum seçeneği ile görüş belirten öğrenci sayısı $f=269(\% 45,7)$ olurken ara tatil uygulamasının aile bireylerini mutlu ettiği yönünde görüş belirten öğrenci sayısı $f=301(\% 51,1)$ olmuştur.

Ara tatil uygulamasına öğrencilerin bakışlarının incelenmek istediği sorulardan oluşan bu bölümde genel olarak öğrencilerin ara tatilde mutlu oldukları sonucuna varılabilir.

\section{Ara Tatil Etkinlikleri ile İlgili Öğrenci Görüşlerine Dair Bulgular}

Ara tatilde öğrencilerin katılabilmesi için milli eğitim müdürlüklerince hazırlanan etkinlikler ile öğrenci görüşleri Tablo 4 'te verilmiştir. 
Tablo 4. Ara Tatil Etkinlikleriyle İlgili Görüşler

\begin{tabular}{lccccccc}
\hline & \multicolumn{2}{c}{ Katılmiyorum } & \multicolumn{2}{c}{ Kararsızım } & \multicolumn{2}{c}{ Katılıyorum } \\
Öğrenci görüşleri & $\mathrm{f}$ & $\%$ & $\mathrm{f}$ & $\%$ & $\mathrm{f}$ & $\%$ \\
\hline $\begin{array}{l}\text { Ara tatilde uygulanan kültürel etkinliklerden } \\
\text { haberdar oldum }\end{array}$ & 331 & 56,2 & 125 & 21,2 & 133 & 22,6 \\
$\begin{array}{l}\text { Arar tatilde çevremde uygulanan kültürel } \\
\text { etkinliklere katılabildim }\end{array}$ & 350 & 59,4 & 113 & 19,2 & 126 & 21,4 \\
$\begin{array}{l}\text { Ara tatilde uygulanan sanatsal etkinliklerden } \\
\text { haberdar oldum }\end{array}$ & 344 & 58,4 & 108 & 18,3 & 137 & 23,3 \\
$\begin{array}{l}\text { Ara tatilde çevremde uygulanan sanatsal } \\
\text { etkinliklere katılabildim }\end{array}$ & 385 & 65,4 & 96 & 16,3 & 108 & 18,3 \\
$\begin{array}{l}\text { Ara tatilde uygulanan sportif etkinliklerden } \\
\text { haberdar oldum }\end{array}$ & 307 & 52,1 & 92 & 15,6 & 190 & 32,3 \\
$\begin{array}{l}\text { Ara tatilde çevremde uygulanan sportif } \\
\text { etkinliklere katılabildim }\end{array}$ & 356 & 60,4 & 84 & 14,3 & 149 & 25,3 \\
$\begin{array}{l}\text { Ara tatilde uygulanan eğlenceli etkinliklerden } \\
\text { haberdar oldum }\end{array}$ & 280 & 47,5 & 85 & 14,4 & 224 & 38 \\
$\begin{array}{l}\text { Ara tatilde çevremde uygulanan eğlenceli } \\
\text { etkinliklere katılabildim }\end{array}$ & 287 & 48,7 & 93 & 15,8 & 209 & 35,5 \\
\hline
\end{tabular}

Tablo 4' e göre $f=331(\% 56,2)$ öğrenci hazırlanan kültürel etkinliklerden haberdar olmadıklarını belirtmişlerdir. Hazırlanan kültürel etkinliklere katılamadığını ifade eden öğrenci sayısı ise $f=350(\% 59,4)$ olmuştur. Bu bilgilerden yola çıkarak öğrencilerin ara tatilde kendileri için hazırlanan kültürel etkinliklerden yeteri kadar haberdar olmadıkları ve bu kültürel etkinliklere katılamadıkları sonucuna varılmıştır.

Ara tatilde hazırlanan sanatsal etkinliklerden haberdar olan öğrenci sayısı $f=137(\% 23,3)$ olurken sanatsal etkinliklerden haberdar olmadım görüşünü belirten öğrenci sayısı $f=344$ $(\% 58,4)$ olmuştur. Yine hazırlanan sanatsal etkinliklere katılabildim yönünde görüş belirten öğrenci sayısı $f=108(\% 18,3)$ iken sanatsal etkinliklere katılamadığını belirten öğrenci sayısı $f=$ $385(\% 65,4)$ olmuştur. Bu bilgiler 1şığında öğrencilerin ara tatilde kendileri için hazırlanan sanatsal etkinliklerden yeterince haberdar olamadıkları ve bu etkinliklere katılamadıkları bilgisine ulaşılmıştır.

Ara tatilde hazırlanan sportif etkinliklerden haberdar olan öğrenci sayısı $f=190(\% 32,3)$ olurken hazırlanan sportif etkinliklerden haberdar olmadığını belirten öğrenci sayısı $f=307$ $(\% 52,1)$ olmuştur. Sportif etkinliklere katılabilen öğrenci sayısı $f=149(\% 25,3)$ olurken hazırlanan sportif etkinliklere katılamadığını belirten öğrenci sayısı $f=356(\% 60,4)$ olmuştur. Bu bilgiler ışı̆ı̆nda öğrencilerin ara tatilde kendileri için hazırlanan sportif etkinliklerden yeterince haberdar olamadıkları ve bu etkinliklere yeterince katılamadıkları söylenebilir. 
Ara tatilde hazırlanan eğlenceli etkinliklerden haberdar olan öğrenci sayısı $f=224$ (\%38) olurken eğlenceli etkinliklerden haberdar olamadım görüşünü belirten öğrenci sayısı $f=280$ $(\% 47,5)$ olmuştur. Çevremde uygulanan eğlenceli etkinliklere katıldım görüşünü belirten öğrenci sayısı $f=209(\% 35,5)$ iken çevremde uygulanan eğlenceli etkinliklere katılamadım yönünde görüş belirten öğrenci sayısı $f=287(\% 48,7)$ olmuştur. Bu bilgilere bakılarak öğrencilerin ara tatilde kendileri için hazırlanan eğlenceli etkinliklerden yeteri kadar haberdar olamadıkları ve yine bu etkinliklere yeteri kadar katılamadıkları anlaşılmaktadır.

\section{Tartışma}

Araştırmanın sonucunda 2019 yılında ilk defa uygulanan 'Ara Tatil' uygulamasından öğrencilerin genel anlamda memnun oldukları anlaşılmaktadır. Öğrencilerin duyuşsal olarak ara tatilden olumlu etkilendikleri sonucuna varılmıştır. Eğitimde kalıcı öğrenme için öğrencilerin duyuşsal özellikleri dikkate alınarak, onların duyguları öğrenme süreçlerine dahil edilmelidir (Gömleksiz ve Kan, 2012).

Ara tatil uygulamasında öğrencilerin çoğunlukla $f=424$ (\%72) kendilerini mutlu hissettikleri, ara tatilde dinlenme fırsatı buldukları, aileleri ile daha fazla zaman geçirebildikleri, ara tatil uygulamasının her sene uygulanmasını istedikleri, ara tatil uygulamasının sadece kendilerini değil aile bireylerini de mutlu ettiği çoğunlukla söylenebilir.

Ara tatil uygulamasında sayıları azımsanmayacak kadar öğrencinin de -anketin ilgili sorusunda kararsız öğrencilerin de eklenmesi ile- $f=165(\% 28)$ bu uygulamadan memnun olmadığı söylenebilir. Bunun sebebinin uygulamanın ilk defa uygulanıyor olması ve milli eğitim müdürlüklerinin yeterince hazırlık yapamadıkları söylenebilir. Çünkü öğrencilerin çok büyük bir bölümü kendileri için hazırlanan bilimsel, kültürel, sanatsal, sportif ve eğlenceli etkinliklerden haberdar olamadıklarını belirtmişlerdir.

Yine öğrencilerden ara tatilde ödev yaparak zaman geçirenler olduğu, ara tatilde oyun oynamayan öğrencilerin bulunduğu, dinlenme fırsatı bulamayan öğrencilerin olduğu tespit edilmiştir. Ara tatilde öğrenciler için hazırlanan etkinliklerden haberdar olma durumu ve etkinliklere katılma oranlarının düşük olduğu görülmüştür.

Araştırma sonucuna göre öğrenciler çevrelerinde hazırlanan bilimsel, kültürel, sanatsal, sportif ve eğlenceli etkinliklerden yeterince haberdar olmamışlar ve bunu devamında bu etkinliklere de yeterince katılamamışlardır. Öğrenciler için hazırlanan bu etkinliklerin öğrencilere duyurulması konusunda eksiklikler yaşandığ 1 söylenebilir. Özellikle köy ve kasabada ikamet eden öğrencilerin kendileri için hazırlanan etkinliklere katılmaları için herhangi bir ulaşım kolaylığı sağlanıp sağlanmadığ1 yönünde bilgi edinilememiştir.

\section{Öneriler}

Araştırmaya katılan öğrencilerin genel anlamda ara tatil uygulamasından memnun oldukların belirtmelerinin yanında memnun olmayan ve ara tatilde istedikleri gibi zaman geçiremeyen öğrencilerin olması dikkati çekmektedir. Milli Eğitim bakanlığınca uygulamanın 
sonuçlarının görülmesi için ülke genelinde bir araştırma yapıp eksikleri ve sorunları tespit etmesinin önemli olduğu düşünülmektedir.

Araştırma sonucunda ara tatilde ödev yapan öğrencilerin varlığının tespit edilmesi ara tatilin amacının dışına çıktığı ve karar alıcıların bu konu üzerinde önemle durması gerektiği, öğretmenleri süreçle ilgili bilgilendirmesi gerekmektedir. Ara tatil süresinde milli eğitim müdürlüklerince öğrenciler için hazırlanan etkinliklerin daha profesyonelce hazırlanması, bu etkinliklerin ara tatilden önce kamuoyu ile paylaşılması, hazırlanan etkinliklerin öğrenci ilgi ve isteklerine göre şekillendirilmesi gerekmektedir.

Öğrencilerin katılması için hazırlanan etkinliklere özellikle köy ve kasaba öğrencilerinin daha rahat ulaşması için ulaşımda gerekli kolaylıkların sağlanmasının gerektiği düşünülmektedir. Aksi takdirde bu öğrencilerin hazırlanan etkinliklere katılım oranının az olacağ görülmektedir.

Karar alıcıların ülke genelindeki tüm öğrenci ve öğretmenleri kapsayan böyle büyük bir değişiklik öncesi paydaşların görüşünün alınmasının uygulamanın sağlıklı yürüyebilmesi için önemli olacağı düşünülmektedir.

\section{Araştırmacıların Katkı Oranı}

Bu çalışmanin her bölümünde yazarlar birlikte hareket etmiş olup, inceleme, gözden geçirme işlemini birlikte yapmışlardır. Her araştırmacı eşit oranda katkı sağlamıştır.

\section{Çatışma Beyanı}

Yazarlar potansiyel bir çıkar çatışması olmadı̆̆ını beyan ederler.

\section{Kaynakça}

Burç, G. ve Karakuyu, A. (2020). Sınıf öğretmenlerinin dönem içerisinde ilk kez uygulanan ara tatil uygulaması hakkındaki görüşleri. Uluslararası Sosyal araştırmalar Dergisi, 13(70). DOI: $10.17719 /$ jisr.2020.4132

Büyüköztürk, Ş. (2005). Anket geliştirme. Türk Ĕğitim Bilimleri Dergisi, 3(2) , 133-151.

Doğan, A. (2020). Sınıf öğretmenlerinin ara tatillere yönelik görüşleri. O. Köse ve Y. UlutürkSakarya (Ed.), Sosyal bilimlerde yeni araştırmalar-III içinde (s. 241-252). Ankara: Berikan Yayıncilik.

Erdem, A ve Kıran, H. (2016). 4+4+4 Eğitim modeline yönelik ilkokul yöneticilerinin görüşleri. OPUS Uluslararası Toplum Araştırmaları Dergisi, 4(7) , 27-49.

European Commission / EACEA / Eurydice, (2019). The organisation of school time in Europe. Primary and general secondary education -2019/20. Eurydice facts and figures. Luxembourg: Publications Office of the European Union. Doi:10.2797/678694. 
Gömleksiz, N, M. ve Kan, Ü.A. (2012). Eğitimde duyuşsal boyut ve duyuşsal öğrenme. Turkish studies, 7(1), 1159-1177. DOI: 10.7827/TurkishStudies.3127

Karasar, N. (2012). Bilimsel araştırma yöntemleri. Ankara: Nobel.

Kaya, S. (2020). Türk Eğitim Sistemi'nde yeni dönem: Ara tatil. Turkish Studies -Educational Sciences, 15(2), 1049-1059. DOI: 10.29228/TurkishStudies.40272

Kaya, S. (2021). Ortaokul öğretmenlerinin ara tatil hakkındaki görüşleri: Bir karma yöntem çalışması. Yüzüncü Yıl Üniversitesi Eğitim Fakültesi Dergisi, 18(1), 21-46. DOI: 10.33711/yyuefd.859357

Kilıç, S. (2013). Örnekleme yöntemleri. Journal Of Mood Disorders, 3(1), 44-6. DOI: 10.5455/jmood.20130325011730

Kıroğlu, K., Tut, E., Aydoğmuş, M. ve Torun, N . (2021). Ara tatilin okuma yazma öğrenme sürecine yansımaları. Ana Dili Ĕ̆gitimi Dergisi, 9(2), 451-469. DOI: 10.16916/aded.868770

MEB. (2017). Araştırma, yarışma ve sosyal etkinlikler izinleri. http://orgm.meb.gov.tr/meb_iys_dosyalar/2017_10/16171246_arastirma_yarisma_sose tkinlik_izinleri.pdf adresinden alınmıştır.

MEB. (2019). Ara tatil uygulamaları. http://aratatil.meb.gov.tr/ adresinden alınmıştır.

MEB. (2019). Bakanlık açıklaması. http://www.meb.gov.tr/bakan-selcuk-yeni-egitimogretimcalisma-takvimi-modelini-acikladi/haber/18662/tr adresinden alınmıştır.

Resmî Gazete (2019a). 30827 sayılı Millî Eğitim Bakanlığı Okul Öncesi Eğitim ve İlköğretim Kurumları Yönetmeliğinde Değişiklik yapılmasına Dair Yönetmelik. https:/www.resmigazete.gov.tr/eskiler/2019/07/20190710-6.html adresinden alınmıştır.

Resmî Gazete (2019b). 30829 sayılı Millî Eğitim Bakanlığı Ortaöğretim Kurumları Yönetmeliğinde Değişiklik yapılmasına Dair Yönetmelik. https://www.resmigazete.gov.tr/eskiler/2019/07/20190712-10.htm adresinden alınmıştır.

Tezcan, M. (1977). Tatil ve boş zamanların değerlendirilmesi. Eğitim ve Bilim Dergisi, 2(9) 5355.

Türk Dil Kurumu (TDK) (2020). Tatil. https://sozluk.gov.tr/ adresinden alınmıştır. 